\title{
Seasonal occurrence of anoxygenic photosynthesis in Tillari and Selaulim reservoirs, Western India
}

\author{
S. Kurian ${ }^{1}$, R. Roy ${ }^{1,2}$, D. J. Repeta ${ }^{2}$, M. Gauns ${ }^{1}$, D. M. Shenoy ${ }^{1}$, T. Suresh ${ }^{1}$, A. Sarkar ${ }^{1}$, G. Narvenkar ${ }^{1}$, \\ C. G. Johnson ${ }^{2}$, and S. W. A. Naqvi ${ }^{1}$ \\ ${ }^{1}$ National Institute of Oceanography, Council of Scientific \& Industrial Research, Dona Paula, Goa, 403 004, India \\ ${ }^{2}$ Woods Hole Oceanographic Institution, Woods Hole, MA 02543, USA
}

Correspondence to: S. Kurian (siby@nio.org)

Received: 30 November 2011 - Published in Biogeosciences Discuss.: 16 December 2011

Revised: 21 May 2012 - Accepted: 23 May 2012 - Published: 9 July 2012

\begin{abstract}
Phytoplankton and bacterial pigment compositions were determined by high performance liquid chromatography (HPLC) and liquid chromatography-mass spectrometry (LC-MS) in two freshwater reservoirs (Tillari Dam and Selaulim Dam), which are located at the foothills of the Western Ghats in India. These reservoirs experience anoxia in the hypolimnion during summer. Water samples were collected from both reservoirs during anoxic periods while one of them (Tillari Reservoir) was also sampled in winter, when convective mixing results in well-oxygenated conditions throughout the water column. During the period of anoxia (summer), bacteriochlorophyll (BChl) $e$ isomers and isorenieratene, characteristic of brown sulfur bacteria, were dominant in the anoxic (sulfidic) layer of the Tillari Reservoir under low light intensities. The winter observations showed the dominance of small cells of Chlorophyll $b$-containing green algae and cyanobacteria, with minor presence of fucoxanthin-containing diatoms and peridinincontaining dinoflagellates. Using total $\mathrm{BChl} e$ concentration observed in June, the standing stock of brown sulfur bacteria carbon in the anoxic compartment of Tillari Reservoir was estimated to be $2.27 \mathrm{gC} \mathrm{m}^{-2}$, which is much higher than the similar estimate for carbon derived from oxygenic photosynthesis $\left(0.82 \mathrm{gC} \mathrm{m}^{-2}\right)$. The Selaulim Reservoir also displayed similar characteristics with the presence of $\mathrm{BChl} e$ isomers and isorenieratene in the anoxic hypolimnion during summer. Although sulfidic conditions prevailed in the water column below the thermocline, the occurrence of photo-autotrophic bacteria was restricted only to mid-depths (maximal concentration of $\mathrm{BChl} e$ isomers was detected at $0.2 \%$ of the surface incident light). This shows that the vertical distribution
\end{abstract}

of photo-autotrophic sulfur bacteria is primarily controlled by light penetration in the water column where the presence of $\mathrm{H}_{2} \mathrm{~S}$ provides a suitable biogeochemical environment for them to flourish.

\section{Introduction}

In stratified lakes having anoxic hypolimnia, photoautotrophic bacteria have been known to contribute substantially to total primary production and biomass (Biebl and Pfennig, 1979; Hurley and Watras, 1991). These bacteria use sulfide and other reduced sulfur compounds and sometimes also iron sulfide as electron donors and light as energy source for anoxygenic photosynthesis (Garcia-Gil et al., 1990; Imhoff, 1992). These bacteria are divided into the purple sulfur bacteria (PSB) and the green sulfur bacteria (GSB). Purple sulfur bacteria are generally pigmented with bacteriochlorophyll (BChl) $a$ or $b$ while green sulfur bacteria contain $\mathrm{BChl} c, d$ or $e$ along with their characteristic carotenoids. The BChls $c, d$ and $e$ exist as a series of homologues that differ in the degree of alkylation of the tetrapyrrole macrocycle at positions C-8 and C-12 and in the esterifying alcohol at C-17 (Senge and Smith, 1995). Green sulfur bacteria such as Chlorobium (Cb.) phaeobacteroides contain a large amount of aggregated $\mathrm{BChl} e$ along with high content of carotenoids in the chlorosome and are brown colored due to the presence of $\mathrm{BChl} e$ aggregates. They also contain minor amounts of BChl $a$ in the photosynthetic reaction centre and also associated with the baseplate of the chlorosome (Gerola and Olson, 1986). A few other GSB such as Cb. tepidum and $C b$. 
limicola look green due to the presence of large aggregated BChl $c$ and $d$, with a low content of carotenoids (Hirabayashi et al., 2004). Recently, the application of HPLC, LC-MS and Tandem mass spectrometry has made the analysis of bacteriochlorophyll isomers more accurate and specific (Airs et al., 2001a, b; Airs and Keely, 2002; Massè et al., 2004).

The accumulation of phototrophic bacteria close to the oxic-anoxic boundary layer depends strongly on the available light (Pfenning, 1989), which can even act as a limiting factor. In comparison with the GSB, the brown-colored species have been shown to live deeper in the water column where the available spectral range is limited to $400-600 \mathrm{~nm}$ (Vila and Abella, 1994).

There have been several studies of photo-autotrophic sulfur bacteria in freshwater lakes (Takahashi and Ichimura, 1968; Yacobi et al., 1990; Garcia-Gil and Abella, 1992; Borrego et al., 1997; Vila et al., 1998; Yacobi and Ostrovski, 2008, 2011). Based on BChl $e$ pigments, Yacobi et al. (1990) reported the dominance of brown sulfur photosynthetic bacteria in the anoxic hypolimnion of Lake Kinneret, Israel. Bacteriochlorophyll homologues composition and changes in relation to light intensity were studied by Borrego et al. (1997) in several meromictic and holomictic lakes of Europe and USA. Meromictic lakes have been found to support dense populations of anaerobic photosynthetic bacteria as the stagnant bottom waters are rich in nitrogen, phosphorus and sulfide with the species variability dependent on light availability and physicochemical characteristics of the lake (Garcia-Gil and Abella, 1992; Borrego et al., 1997).

India has a large number of natural freshwater lakes and man-made reservoirs created by damming rivers, some of which have recently been found to experience anoxic conditions including sulphate reduction in the hypolimnia during summer (Narvenkar et al., 2012). We selected two such systems - the reservoirs of Tillari and Selaulim dams - to undertake a study of phytoplankton and bacterial pigments in Indian freshwater lakes, the results of which are being reported here. These reservoirs are located at the foothills of the Western Ghats in the states of Maharashtra (Tillari) and Goa (Selaulim) (Fig. 1). The former is currently being sampled by us at least once a month since March 2010. This reservoir has been found to be dimictic in that the water column gets vertically mixed during winter and southwest monsoon periods. In 2010, when sampling for anoxygenic photosynthetic organisms was carried out, sulfidic conditions prevailed from May to July before being terminated by re-oxygenation of the hypolimnion through groundwater inputs as well as weakening of thermal stratification followed by wind-induced mixing during the southwest monsoon. At the end of the southwest monsoon, stratification was re-established and the hypolimnion again lost oxygen, but it did not become anoxic. Convective mixing led to the development of well-oxygenated conditions during the following winter (S. W. A. Naqvi, unpublished data). Based on HPLC and LC-MS analyses, we investigate the variability of

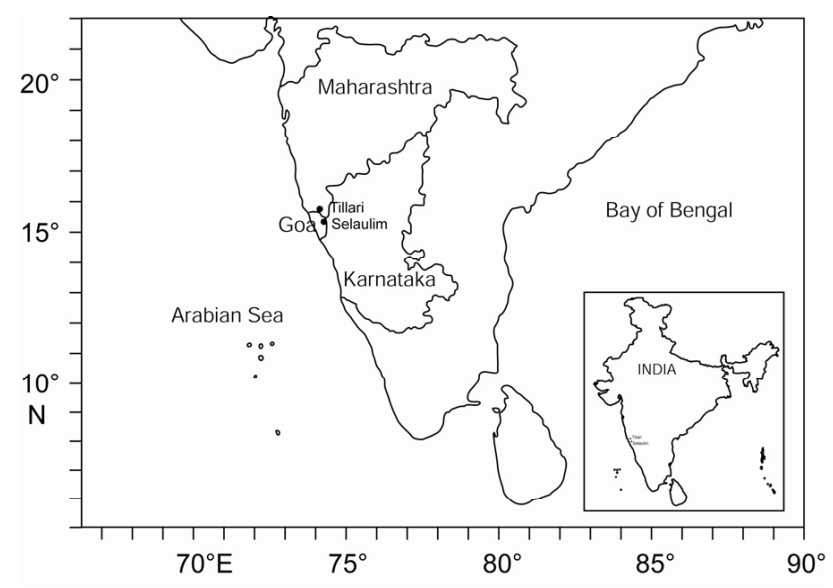

Fig. 1. Sampling locations (Tillari Reservoir and Selaulim Reservoir) situated in central India. Tillari Reservoir is located in the Maharashtra state with storage capacity of $0.45 \times 10^{9} \mathrm{~m}^{3}$ and water depth of $\sim 50 \mathrm{~m}$, while Selaulim Reservoir is located in the Goa state with lower storage capacity $\left(0.23 \times 10^{9} \mathrm{~m}^{3}\right)$ and shallower depth $(\sim 20 \mathrm{~m})$. Both these reservoirs were found to turn anoxic during summer.

phytoplankton and bacterial pigments in relation to the development of water column anoxia during May-July 2010. We compare these data with one observation during winter (January 2011). In Selaulim Reservoir, which has a smaller storage capacity $\left(0.23 \times 10^{9} \mathrm{~m}^{3}\right.$ as compared to $0.45 \times 10^{9} \mathrm{~m}^{3}$ for the Tillari Reservoir), observations were made only once - in May 2010 - when intense anoxia prevailed in the hypolimnion. Finally, an attempt is made to quantify the relative contribution of oxygenic and anoxygenic photo-autotrophs to microbial biomass during summer in the Tillari Reservoir.

\section{Methodology}

Water sampling in the reservoirs was carried out using 5-1 Niskin samplers mounted on a nylon wire and fitted with reversing thermometers to measure temperature at different sampling depths. Subsamples for dissolved oxygen (DO) and hydrogen sulfide $\left(\mathrm{H}_{2} \mathrm{~S}\right)$ were collected carefully avoiding air exchange and taken to the laboratory for analysis. Dissolved oxygen and $\mathrm{H}_{2} \mathrm{~S}$ were estimated following standard titrimetric Winkler and colorometric methods, respectively (Grasshoff et al., 1983).

Optical parameters were derived using the radiative transfer simulation code Hydrolight Version 5.0 (http://www. sequoia.com). The inputs to the simulations were absorption and beam attenuation at nine wavelengths measured in situ using the AC-9 spectrophotometer (WET Labs, Inc.) and solar irradiance at the surface. The downwelling solar irradiance for the day was derived using the solar irradiance model (Gregg and Carder, 1990). Aerosol optical depth at $550 \mathrm{~nm}$, Angstrom exponent, ozone and pressure for the day were 
derived from ocean color satellite MODIS Aqua available from Giovanni GES-DISC (Goddard Earth Sciences Data and Information Services Center) (http://disc.sci.gsfc.nasa. gov/giovanni). Other meteorological parameters such as the wind speed and humidity were derived using climatological data over the region. The volume scattering function for the Hydrolight simulations was from Petzold (1972).

For the pigment analysis, water samples were collected in amber colored bottles and were filtered $(\sim 0.5$ to $1 \mathrm{l})$ on Whatman glass fibre filters $(\mathrm{GF} / \mathrm{F}$; pore size $0.7 \mu \mathrm{m})$ under dark conditions and stored at $-80^{\circ} \mathrm{C}$ until the analysis. The frozen filters were extracted within $2-3$ weeks of collection at $0{ }^{\circ} \mathrm{C}$ for $2 \mathrm{~min}$ in $3 \mathrm{ml}$ of $100 \%$ methanol using ultrasonic dismembrator model 100 (Fisher Scientific) at $23 \mathrm{kHz}$. The extracts were filtered using a Teflon syringe cartridge (Sartorius Minisart, pore size $0.45 \mathrm{~mm}$, diameter $25 \mathrm{~mm}$ ) to remove any cellular debris, and analyzed using HPLC (Agilent Technologies) at the National Institute of Oceanography (NIO), Goa using an Eclipse XDB C8 column. Pigments were separated following the procedure as detailed in Roy et al. (2006) using a binary solvent gradient. Briefly, elution was performed at a rate of $1.1 \mathrm{ml} \mathrm{min}^{-1}$ using a linear gradient program over $45 \mathrm{~min}$ as follows: initially $5 \%$ of solvent B (methanol) followed by a linear gradient over 22 min to $95 \% \mathrm{~B}$, with an isocratic hold for $13 \mathrm{~min}$ at $95 \% \mathrm{~B}$ until $35 \mathrm{~min}$, which returned to initial condition of $5 \%$ B prior to the next analysis. Solvent A was 70/30: methanol/0.5 M ammonium acetate and the column was maintained at $60^{\circ} \mathrm{C}$ during the analysis. The eluting pigments were detected at 450 and $665 \mathrm{~nm}$ (Soret and Qy bands) by the diode array detector. Commercially available standards obtained from DHI Inc. (Denmark) were used for the identification and quantification of pigments including both chlorophylls and carotenoids. Identification was based on the retention time and visible spectra matching. Pigment concentrations were computed from the peak areas as detailed in Roy et al. (2006).

Bacteriochlorophylls were identified and quantified by HPLC and LC-MS at Woods Hole Oceanographic Institution (WHOI), USA. Extraction of samples was done using acetone in ultrasonic bath, dried and re-dissolved in methanol and analysed by HPLC (Agilent Technologies) equipped with C-18 column $(15 \mathrm{~cm} \times 4.6 \mathrm{~mm}, 3 \mu \mathrm{m}$, Supelco Inc $)$. Elution was performed at a rate of $1.5 \mathrm{ml} \mathrm{min}^{-1}$ for $60 \mathrm{~min}$ using a linear gradient program with the eluent composition varying as follows: $100 \%$ solvent $\mathrm{A}(80 / 20: \mathrm{MeOH} / 0.05 \mathrm{M}$ ammonium acetate) to begin with, followed by a linear gradient over $20 \mathrm{~min}$ to $100 \% \mathrm{~B}$ (80/20: $\mathrm{MeOH} /$ acetone); an isocratic hold for 25 min with $100 \%$ B for elution of all the major pigments then returning to $100 \%$ A for $5 \mathrm{~min}$; finally, 10 min hold with $100 \%$ A to equilibrate the column before next analysis. Pigments were detected at 410, 442, 470 and $660 \mathrm{~nm}$ by the diode array detector (DAD). Even though different HPLC columns were used in NIO (C-8) and WHOI (C-18), the BChl peaks were well resolved under the above- mentioned conditions in both cases, appearing a little earlier (by 1.4-1.9 $\mathrm{min}$ ) when the $\mathrm{C} 18$ column was used.

Samples were also analyzed by LC-MS (Agilent Technologies) using an atmospheric pressure chemical ionization (APCI) source operated in the positive ion mode, scanning from 300 to $1200 \mathrm{~m} / z$. The same column and eluting solvents were used and the peaks were confirmed based on mass spectra in full scan and also in the selected ion monitoring (SIM) mode. Conditions used for LC-MS analysis were: vaporizer temperature $400^{\circ} \mathrm{C}$, drying gas temperature $300^{\circ} \mathrm{C}$ and discharge current $3 \mu \mathrm{A}$. Bacteriochlorophyll standards were extracted from particulate matter from Salt Pond, USA, in which $\mathrm{BChl} e$ isomers were dominant. Bacteriochlorophyll homologues were separated using fraction collector and quantified by spectrophotometic measurements assuming a molar extinction coefficient $48.9 \mathrm{mM} \mathrm{cm}^{-1}$ (Borrego et al., 1999a). A multi-point calibration table was prepared for $\mathrm{BChl} e 4$ isomer and the same calibration was used for $\mathrm{BChl}$ $e 2$ and $e 3$ isomers as they are different only by $\mathrm{CH}_{2}$ groups. Isorenieratene was quantified based on $\beta$-carotene calibration and was present in the anoxic samples. The standing stock of anoxygenically photosynthesized carbon was estimated from the column-integrated $\mathrm{BChl} e$ using $\mathrm{BChl} e: \mathrm{C}$ ratio of 1:20 (Oelze and Golecki, 1988; Yacobi and Ostrovski, 2008). Similarly, the standing stock of oxygenically photosynthesized carbon was calculated using a Chl $a: \mathrm{C}$ ratio of $1: 40$ (Cole et al., 2002).

Sub-samples $(1.5 \mathrm{ml})$ were also collected and preserved with glutaraldehyde ( $0.25 \%$ final concentration), frozen in liquid nitrogen and then stored at $-80^{\circ} \mathrm{C}$ for flow cytometric analysis at NIO. These samples were thawed at room temperature and analysed using a FACS Calibur flow cytometer following Marie et al. (1997) to obtain absolute counts. A combination of the FSC (forward scatter)-SSC (side scatter), the SSC-FL3 (red fluorescence) and the FL2 (orange fluorescence) - FL3 plots were used to differentiate populations in the sample (Casamayor et al., 2007). The data was analyzed using CYTOPC software (Vaulot, 1989). A culture of photosynthetic sulfur bacteria isolated from the seasonal anoxic marine waters off Goa (September, 2006) at a depth of $25 \mathrm{~m}$ was run to identify this form from other fields. The culture was maintained in Pfenning's medium (Pfenning, 1989; Pfenning and Trüper, 1989, 1992) at a pH of 6.6-6.8 which was previously purged with nitrogen and later saturated with $\mathrm{CO}_{2}$ gas. The non-axenic culture medium was periodically added with neutral solution of sodium sulfide with a final concentration being $416 \mu \mathrm{M}$ to replenish the photosynthetic electron donors and sodium acetate (final conc. $1 \mu \mathrm{M}$ ). HPLC analysis of the culture (brown in colour) showed the dominance of different $\mathrm{BChl} e$ isomers, confirming the enrichment of GSB in the culture. 


\section{Results}

\subsection{Tillari Reservoir}

\subsubsection{Hydrographic conditions}

During May and June, the water column was strongly stratified, with a surface-to-bottom temperature difference of $\sim 7^{\circ} \mathrm{C}$ (Figs. 2a and 3a), and contained distinct biogeochemical regimes, i.e., oxic epilimnion separated from the anoxic hypolimnion. In May, DO was close to detection limit at and below $20 \mathrm{~m} ; \mathrm{H}_{2} \mathrm{~S}$ was present at and below $25 \mathrm{~m}$, with concentrations reaching up to $8.3 \mu \mathrm{M}$ close to the bottom ( $\sim 50 \mathrm{~m}$, Fig. 2a). Similar conditions prevailed in June as well with the anoxic layer appearing to have become slightly shallower when compared to the previous month. The highest $\mathrm{H}_{2} \mathrm{~S}$ concentration observed on this occasion was $9 \mu \mathrm{M}$ (Fig. 3a). In July, $\mathrm{H}_{2} \mathrm{~S}$ concentration in the anoxic bottom waters had declined to $3.2 \mu \mathrm{M}$ (data not shown). Stratification broke down during winter (January 2011), with the surface to bottom temperature difference being only $\sim 1{ }^{\circ} \mathrm{C}$, and the water column was well oxygenated. In June, computed light irradiance at the surface was $1523.4 \mu \mathrm{mol}$ photon $\mathrm{m}^{-2} \mathrm{~s}^{-1}$, which decreased to $0.0565 \mu$ mol photon $\mathrm{m}^{-2} \mathrm{~s}^{-1}$ at the bottom of the reservoir.

\subsubsection{Phytoplankton pigments}

In the Tillari Reservoir, chlorophyll $a$ (Chl $a$ ) concentration was $2.06 \mu \mathrm{gl}^{-1}$ at the surface in May, decreasing to $0.04 \mu \mathrm{g} \mathrm{l}^{-1}$ in bottom waters (50 m; Table 1). Surface Chl $a$ decreased to $1.76 \mu \mathrm{gl}^{-1}$ in June and to $0.55 \mu \mathrm{g} 1^{-1}$ in July (Table 1). During most observations, Chl $a$ concentrations remained low in the metalimnion; however, when anoxic conditions prevailed, this layer became enriched with $\mathrm{BChl} e$ isomers (Table 1) and most other pigments were either absent or below detection limits. During summer stratification (MayJuly, 2010), BChl $e$ homologues, characteristic of brown sulfur bacteria represent the major peaks (a, b and c) in Fig. 4a, which were identified based on UV/Vis and APCI-LC-MS spectra and also by comparing with proper $\mathrm{BChl} e_{\mathrm{F}}$ standards. Based on the $m / z$ molecular ions of these isomers $(821.5,835.5$ and 849.5) and their respective fragment ions (through the loss of $\mathrm{H}_{2} \mathrm{O}$ molecule; $-18 \mathrm{AMU}$ ) in each spectrum (Fig. 4b, c and d) and published literature, these were identified as farnesyl-esterified bacteriochlorophyll (BChl $e_{\mathrm{F}}$ ) homologues such as $e 2$ (Et, Et), $e 3$ (n-Pr, Et) and $e 4$ (i-Bu, Et) (Airs et al., 2001b; Glaeser et al., 2002, Massé et al., 2004). BChl $e 2$ varied from below detection limit (BDL) to $2 \mu \mathrm{g} 1^{-1}$ with a mean concentration of $0.06 \mu \mathrm{g} 1^{-1}$. Similarly, $\mathrm{BChl} e 3$ and $e 4$ concentration ranged between BDL and $3.97 \mu \mathrm{g} 1^{-1}$, and BDL and $3.52 \mu \mathrm{g} 1^{-1}$, respectively (Table 1). These isomers were present close to the oxic-anoxic interface and were detectable even at $11 \mathrm{~m}$ depth, where the water was suboxic $\left(0.17 \mathrm{ml} \mathrm{O}_{2} \mathrm{l}^{-1}\right)$ in June. The highest concentration

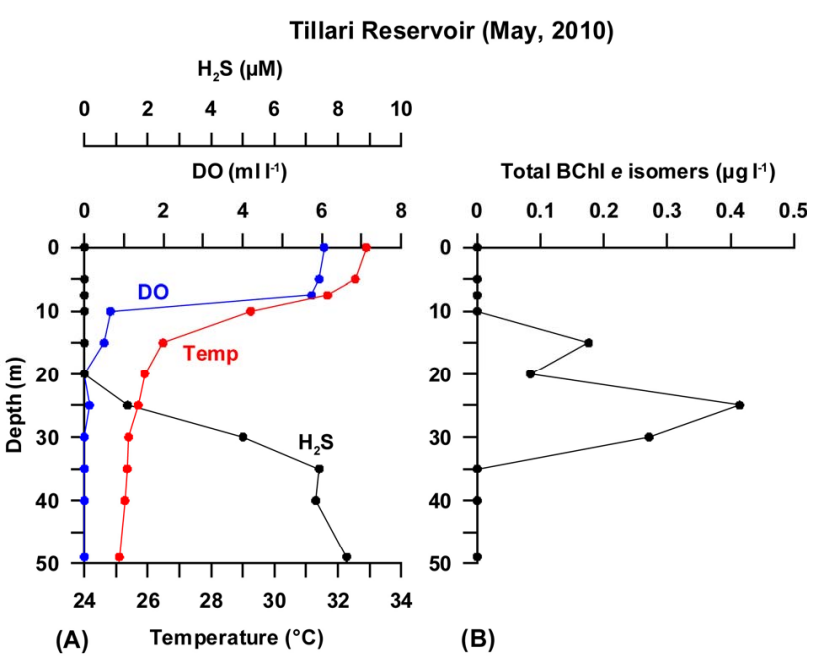

Fig. 2. (A) Vertical profiles of temperature $\left({ }^{\circ} \mathrm{C}\right)$, dissolved oxygen (DO; $1 \mathrm{ml} \mathrm{l}^{-1}=1.42 \mathrm{mg} \mathrm{l}^{-1}$ ) and $\mathrm{H}_{2} \mathrm{~S}(\mu \mathrm{M})$ in Tillari Reservoir during 12 May 2010. During summer stratification, water column turned to be sulfidic below $25 \mathrm{~m}$ depth. (B) Vertical profile of total $\mathrm{BChl} e$ isomers $\left(e 2+, e 3+e 4, \mu \mathrm{gl}^{-1}\right)$ in Tillari Reservoir.

$\left(e 2+e 3+e 4=9.5 \mu \mathrm{g} \mathrm{l}^{-1}\right)$ was measured at $23 \mathrm{~m}$ where the $\mathrm{H}_{2} \mathrm{~S}$ concentration was $0.42 \mu \mathrm{M}$ (Fig. $3 \mathrm{a}$ and b). The $\mathrm{H}_{2} \mathrm{~S}$ concentration increased to $9 \mu \mathrm{M}$ below $23 \mathrm{~m}$, but the concentration of BChl $e$ decreased. The computed light irradiance data show that $15.4 \mu \mathrm{mol}$ photon $\mathrm{m}^{-2} \mathrm{~s}^{-1}(\sim 1 \%$ of the surface incident light) reached $11 \mathrm{~m}$ where $\mathrm{BChl} e$ isomers first appeared, and only $0.2 \%$ of the surface incident light (3.1 $\mu$ mol photon $\left.\mathrm{m}^{-2} \mathrm{~s}^{-1}\right)$ reached $23 \mathrm{~m}$ where the maxima in $\mathrm{BChl} e$ isomers were located (Fig. 3c). Isorenieratene, a carotenoid characteristic of brown sulfur bacteria was also identified based on mass spectrum $(\mathrm{m} / \mathrm{z}$ 529.3) at the depths where $\mathrm{BChl} e_{\mathrm{F}}$ homologues were present in June (range BDL $-0.19 \mu \mathrm{g}^{-1}$, Fig. 3b).

The highest Chl $a$ concentration $\left(2.26 \mu \mathrm{gl}^{-1}\right)$ was observed in January 2011 (Table 1). Apart from Chl $a$, other chemotaxonomic pigments identified were chlorophyll $b$, zeaxanthin, fucoxanthin which represent green algae, cyanobacteria and diatoms, respectively. Other minor pigments associated with the green algae (Chlorophyceace) such as neoxanthin, violaxanthin and lutein were also found during the January observation (Table 1). Chlorophyll $b$ showed a temporal variation similar to Chl $a$, but the concentrations were lower by an order of magnitude. The highest concentration $\left(0.28 \mu \mathrm{gl}^{-1}\right)$ was observed in winter. Zeaxanthin, a marker pigment of cyanobacteria was present in higher concentrations in May (surface) and January and contributed significantly to the biomass structure in the Tillari Reservoir (Table 1). Fucoxanthin also showed similar distribution pattern, but its concentration was lower than those of zeaxanthin and Chl $b$. Peridinin, a marker pigment of dinoflagellates was present during May-August. 
Table 1. Concentration of pigments $\left(\mu \mathrm{g}^{-1}\right)$ in the Tillari Reservoir during May, June, July, 2010 and January, 2011. Abbreviations are as follows: Total Chlorophyll (TChl), Bacteriochlorophyll (BChl), Phaeophytin (Phaeo), Isorenieratene (Isoren), Zeaxanthin (Zea), Peridinin (Per), Fucoxanthin (Fuco), Alloxanthin (Allo), Total carotene (Tcar), Neoxanthin (Neo), Violaxanthin (Viola), Lutein (Lut), Diadinoxanthin (Diad), Diatoxanthin (Diat). - refers "Below Detection Limit". Chlorophylls, BChls and isoren were measured at WHOI, while other carotenoids were quantified at NIO. BChl $e 2$ represents (Et, Et), $e 3$ (n-Pr, Et) and $e 4$ (i-Bu, Et) homologues.

\begin{tabular}{|c|c|c|c|c|c|c|c|c|c|c|c|c|c|c|c|c|c|}
\hline \multicolumn{18}{|c|}{ Field Trip 12/05/2010 } \\
\hline Depth (m) & TChl $a$ & Chl $b$ & BChl $e 2$ & BChl $e 3$ & BChl $e 4$ & Phaeo $a$ & Isoren & Zea & Per & Fuco & Allo & Tcar & $\mathrm{Neo}$ & Viola & Lut & Diad & Diato \\
\hline 0 & 2.06 & 0.13 & - & - & - & 0.02 & - & 0.17 & 0.03 & 0.01 & 0.003 & 0.023 & 0.040 & 0.013 & 0.030 & 0.011 & 0.002 \\
\hline 5 & 0.15 & - & - & - & - & 0.08 & - & - & - & - & - & - & - & - & - & - & 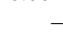 \\
\hline 10 & 0.61 & - & - & - & - & 0.01 & - & - & - & - & - & - & - & - & - & - & - \\
\hline 15 & 0.79 & 0.06 & 0.05 & 0.96 & 0.07 & 0.02 & - & - & - & - & 0.03 & 0.002 & - & - & - & - & - \\
\hline 20 & 0.09 & 0.02 & 0.08 & 0.26 & 0.15 & 0.01 & - & - & - & - & - & - & - & - & - & - & - \\
\hline 25 & 0.04 & - & 0.16 & 0.2 & - & - & - & - & - & - & - & - & - & - & - & - & - \\
\hline 30 & 0.15 & - & 0.09 & 0.12 & 0.11 & 0.02 & - & - & - & - & - & - & - & - & - & - & - \\
\hline 35 & 0.13 & - & - & - & - & 0.02 & - & - & - & - & - & - & - & - & - & - & - \\
\hline 40 & 0.19 & - & - & - & - & 0.02 & - & - & - & - & - & - & - & - & - & - & - \\
\hline 50 & 0.04 & - & - & - & - & 0.02 & - & - & - & - & - & - & - & - & - & - & - \\
\hline \multicolumn{18}{|c|}{ Field Trip 01/06/2010 } \\
\hline 0 & 1.76 & 0.11 & - & - & - & 0.03 & - & 0.07 & 0.03 & 0.004 & - & 0.008 & 0.027 & 0.009 & 0.017 & 0.008 & 0.004 \\
\hline 5 & 1.19 & 0.07 & - & - & - & 0.01 & - & 0.11 & 0.01 & 0.004 & - & 0.005 & 0.026 & 0.002 & 0.005 & 0.010 & 0.004 \\
\hline 11 & 1.32 & 0.07 & 0.46 & 0.99 & 0.72 & 0.01 & 0.09 & - & - & - & - & 0.002 & 0.016 & 0.003 & 0.005 & - & - \\
\hline 15 & 0.37 & - & 0.32 & 0.64 & 0.46 & 0.24 & 0.07 & - & - & - & - & - & - & - & - & - & - \\
\hline 23 & 0.09 & - & 2.0 & 3.97 & 3.52 & 0.10 & 0.2 & - & - & - & - & - & - & - & - & - & - \\
\hline 35 & 0.04 & - & 0.06 & 0.07 & 0.07 & - & - & - & - & - & - & - & - & - & - & - & - \\
\hline 40 & 0.15 & 0.05 & 0.19 & 0.35 & 0.29 & 0.04 & - & 0.04 & 0.06 & 0.01 & - & - & 0.018 & 0.002 & 0.002 & 0.013 & 0.002 \\
\hline \multicolumn{18}{|c|}{ Field Trip 22/07/2010 } \\
\hline 0 & 0.55 & 0.05 & - & - & - & - & - & 0.07 & 0.02 & 0.008 & 0.003 & 0.008 & 0.013 & 0.002 & 0.004 & 0.008 & 0.004 \\
\hline 5 & 0.29 & 0.09 & - & - & - & - & - & 0.05 & 0.01 & 0.005 & 0.008 & 0.004 & 0.003 & 0.001 & 0.004 & 0.002 & 0.001 \\
\hline 10 & 0.44 & 0.04 & - & - & - & - & - & 0.09 & - & - & - & - & 0.005 & 0.002 & 0.004 & 0.003 & 0.003 \\
\hline 15 & 0.10 & - & - & - & - & - & - & 0.01 & - & - & - & - & - & - & - & - & - \\
\hline 20 & 0.00 & - & 0.35 & 0.64 & 0.48 & - & - & - & - & - & - & - & - & - & - & - & - \\
\hline 30 & 0.07 & - & 0.12 & 0.22 & 0.18 & - & - & - & - & - & - & - & - & - & - & - & - \\
\hline 40 & 0.19 & - & - & - & - & - & - & - & - & - & - & - & - & - & - & - & - \\
\hline \multicolumn{18}{|c|}{ Field Trip 13/01/2011 } \\
\hline 0 & 2.27 & 0.21 & - & - & - & 0.03 & - & 0.2 & - & 0.017 & 0.009 & 0.007 & 0.04 & 0.009 & 0.006 & 0.010 & 0.009 \\
\hline 5 & 2.82 & 0.29 & - & - & - & - & - & - & - & 0.014 & 0.014 & 0.007 & 0.01 & 0.004 & 0.01 & 0.014 & 0.012 \\
\hline 10 & 1.49 & 0.17 & - & - & - & 0.04 & - & 0.11 & - & 0.006 & 0.007 & 0.007 & 0.01 & 0.003 & 0.008 & 0.013 & 0.003 \\
\hline 20 & 2.16 & 0.21 & - & - & - & 0.03 & - & 0.13 & 0.02 & 0.008 & 0.015 & 0.008 & 0.02 & 0.007 & 0.018 & 0.009 & 0.004 \\
\hline 40 & 1.27 & 0.12 & - & - & - & 0.002 & - & 0.10 & - & - & - & 0.010 & 0.004 & 0.007 & 0.008 & 0.007 & 0.004 \\
\hline
\end{tabular}

Nonmarker photoprotective xanthophylls such as diadinoxanthin and diatoxanthin were also present in these samples; with comparatively higher concentrations in January $(0.014$ and $0.012 \mu \mathrm{g} 1^{-1}$, respectively; Table 1 ).

\subsubsection{Flow cytometric identification and enumeration of photosynthetic sulfur bacteria}

Flow cytometric analyses of samples collected from Tillari Reservoir in June was carried out for identifying the dominant groups in the anoxic waters. By comparing flow cytograms from a culture of photosynthetic sulfur bacteria (Fig. 5a) with those obtained from the natural population, we could resolve the identity of the microbial population thriving at the anoxic layer between 11 and $35 \mathrm{~m}$ (data for $23 \mathrm{~m}$ are shown in Fig. 5c). This group showed clear sub-surface maxima with peak abundance $\left(1.7 \times 10^{8}\right.$ cells $\left.^{-1}\right)$ between 15 and $23 \mathrm{~m}$ and negligible concentrations at the surface and near bottom waters (Fig. 5b and d); a trend similar to HPLC based bacteriocholorophyll $e$ distribution.

\subsection{Selaulim Reservoir}

The Selaulilm Reservoir is shallower (maximum depth $\sim 20 \mathrm{~m}$ at the time of our sampling) as compared to the Tillari Reservoir. During our sampling in May 2010, the water column was strongly stratified with the surface-to-bottom temperature difference of $\sim 6^{\circ} \mathrm{C}$ (Fig. 6a). The DO disappeared at $9 \mathrm{~m}$, and $\mathrm{H}_{2} \mathrm{~S}$ was present below $12 \mathrm{~m}$ with the highest concentration $(5.7 \mu \mathrm{M})$ occurring at $18 \mathrm{~m}$ (Table 2). Chlorophyll $a$ and zeaxanthin were restricted to the epilimnion, although their concentrations were much lower than the Tillari Reservoir. Farnesyl-esterified $\mathrm{BChl} e$ homologues $(e 2, e 3$ and $e 4$ isomers) were present at $9 \mathrm{~m}$ and below all the way down to the deepest sampling depth. The highest concentrations of total BChl $e$ isomers $\left(6.4 \mu \mathrm{g} \mathrm{l}^{-1}\right)$ were found at $15 \mathrm{~m}$ where $\mathrm{H}_{2} \mathrm{~S}$ concentration was $1.83 \mu \mathrm{M}$ (Fig. 6b). Our data showed 
Table 2. Temperature $\left({ }^{\circ} \mathrm{C}\right)$, concentration of DO $\left(\mathrm{ml} \mathrm{l}^{-1}\right), \mathrm{H}_{2} \mathrm{~S}(\mu \mathrm{M})$ and pigments $\left(\mu \mathrm{g} 1^{-1}\right)$ in the Selaulim Reservoir during 21/05/2010. refers "Below Detection Limit". BChl $e 2$ represents (Et, Et), $e 3$ (n-Pr, Et) and $e 4$ (i-Bu, Et) homologues.

\begin{tabular}{lrrrrrrrr}
\hline $\begin{array}{l}\text { Depth } \\
(\mathrm{m})\end{array}$ & $\begin{array}{r}\text { Temp } \\
\left({ }^{\circ} \mathrm{C}\right)\end{array}$ & $\begin{array}{r}\mathrm{DO} \\
\left(\mathrm{ml}^{-1}\right)\end{array}$ & $\begin{array}{r}\mathrm{H}_{2} \mathrm{~S} \\
(\mu \mathrm{M})\end{array}$ & $\begin{array}{r}\mathrm{BChl} e 2 \\
\left(\mu \mathrm{g}^{-1}\right)\end{array}$ & $\begin{array}{r}\mathrm{BChl} e 3 \\
\left(\mu \mathrm{g} 1^{-1}\right)\end{array}$ & $\begin{array}{r}\mathrm{BChl} e 4 \\
\left(\mu \mathrm{g} \mathrm{I}^{-1}\right)\end{array}$ & $\begin{array}{r}\mathrm{Chl} a \\
\left(\mu \mathrm{g} 1^{-1}\right)\end{array}$ & $\begin{array}{r}\text { Isoren } \\
\left(\mu \mathrm{g} 1^{-1}\right)\end{array}$ \\
\hline 1 & 33.0 & 4.47 & 0.00 & - & - & - & 0.43 & - \\
3 & 32.6 & 4.45 & 0.00 & - & - & - & 0.33 & - \\
6 & 32.0 & 2.80 & 0.00 & - & - & - & 0.55 & - \\
9 & 29.5 & 0.05 & 0.00 & 0.37 & 0.89 & 0.77 & - & 0.23 \\
12 & 27.4 & 0.00 & 0.00 & 0.61 & 1.17 & 1.07 & - & 0.26 \\
15 & 26.8 & 0.00 & 1.83 & 1.19 & 2.78 & 2.39 & - & 0.39 \\
18 & 26.6 & 0.00 & 5.72 & 0.65 & 1.39 & 1.22 & - & 0.24 \\
\hline
\end{tabular}

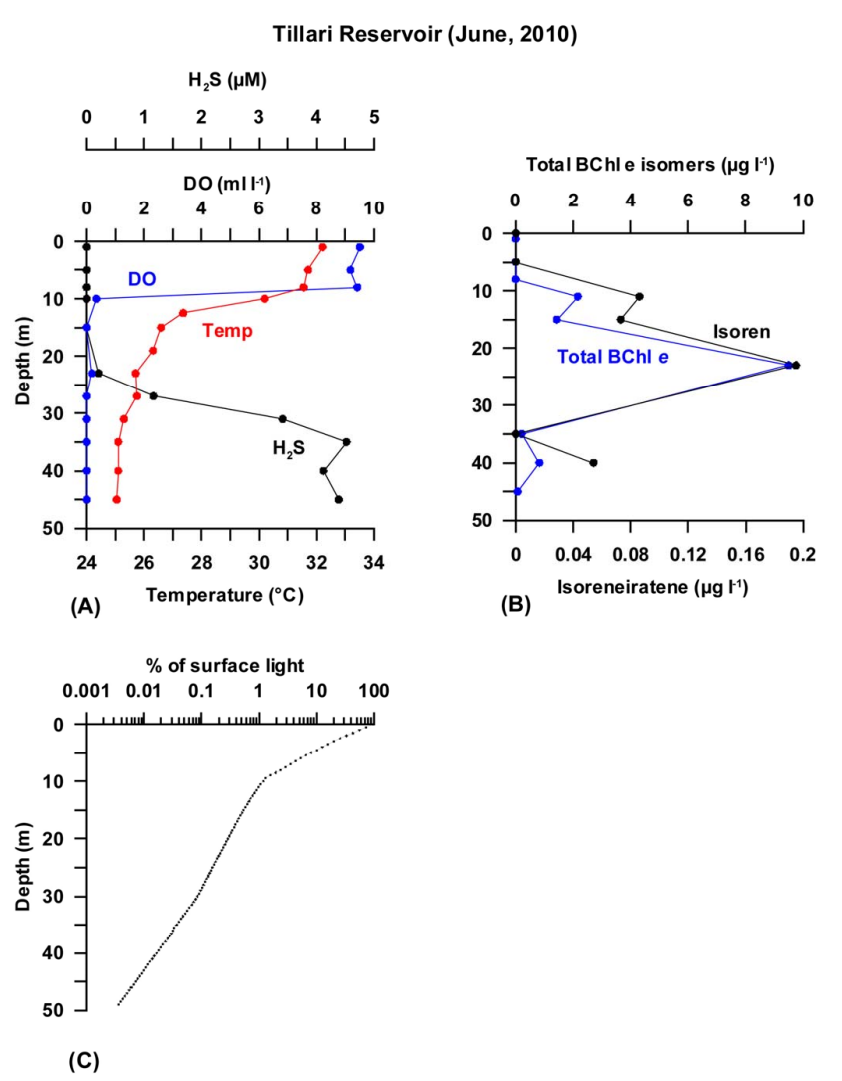

Fig. 3. (A) Vertical profiles of temperature $\left({ }^{\circ} \mathrm{C}\right)$, dissolved oxygen (DO; $1 \mathrm{ml} \mathrm{l}^{-1}=1.42 \mathrm{mgl}^{-1}$ ) and $\mathrm{H}_{2} \mathrm{~S}(\mu \mathrm{M})$ in Tillari Reservoir during 1 June 2010. (B) Vertical profiles of total BChl $e$ isomers $(e 2+e 3+e 4)$ and isorenieratene $\left(\mu \mathrm{gl}^{-1}\right)$ in Tillari Reservoir. $(\mathbf{C})$ $\%$ of light irradiance calculated as described in Sect. 2.

the presence of brown sulfur bacteria in this reservoir too as indicated by the presence of $\mathrm{BChl} e$ homologues and isorenieratene.

\section{Discussion}

\subsection{Comparison of phytoplankton assemblages during summer stratification and winter mixing in the Tillari Reservoir}

The observed seasonal changes in stratification in the Tillari Reservoir not only result in the establishment of contrasting redox regimes (anoxia in the hypolimnion during summer), but also differential availability of nutrients in the surface layer (macro nutrient limitation during summer). During peak stratification, the epilimnion is $<10 \mathrm{~m}$ thick, such that the metalimnion and part of the hypolimnion receive significant amounts of sunlight (e.g. $18.4 \mu \mathrm{mol}$ photon $\mathrm{m}^{-2} \mathrm{~s}^{-1}$ at $10 \mathrm{~m}$ corresponding to $1.2 \%$ of the surface incident light; Fig. 3c). These changes in physico-chemical characteristics of the reservoir are systematically reflected in the phytoplankton community structure. During the period of strong stratification (May-July), the community within the epilimnion mainly consists of smaller nanoflagellates, cyanobacteria, diatoms and dinoflagellates as indicated by the presence of zeaxanthin, Chl $b$, fucoxanthin, peridinin and alloxanthin (Table 1). There is also evidence for anoxygenic photosynthesis (based on presence of $\mathrm{BChl} e$ ) in the metalimnion and hypolimnion as discussed in Sect. 4.2. The HPLC based pigment data are consistent with the flow cytometry data. Earlier work of Casamayor et al. (2007) shows the potential of flow cytometry as a fast tool for population identification and enumeration of photosynthetic sulfur bacteria. Using this tool the natural samples from the Tillari Reservoir were analysed against the mixed culture of photoautotrophic sulfur bacteria, which showed that these bacteria are the dominant constituent of the autotrophic picoplankton community at $\sim 15-27 \mathrm{~m}$ depth (suboxic/anoxic waters of the metalimnion and upper hypolimnion; Fig. 5). However, maximum abundance of these bacteria $\left(1.7 \times 10^{8} 1^{-1}\right.$ at $23 \mathrm{~m}$ ) found in the present study were much lower than those of brown sulfur bacteria $\left(8.6 \times 10^{8} 1^{-1}\right)$ reported from the Lake Vilar at shallow depth $(5 \mathrm{~m})$ under sulfidic condition (Bañeras and Garcia-Gil, 1996). 

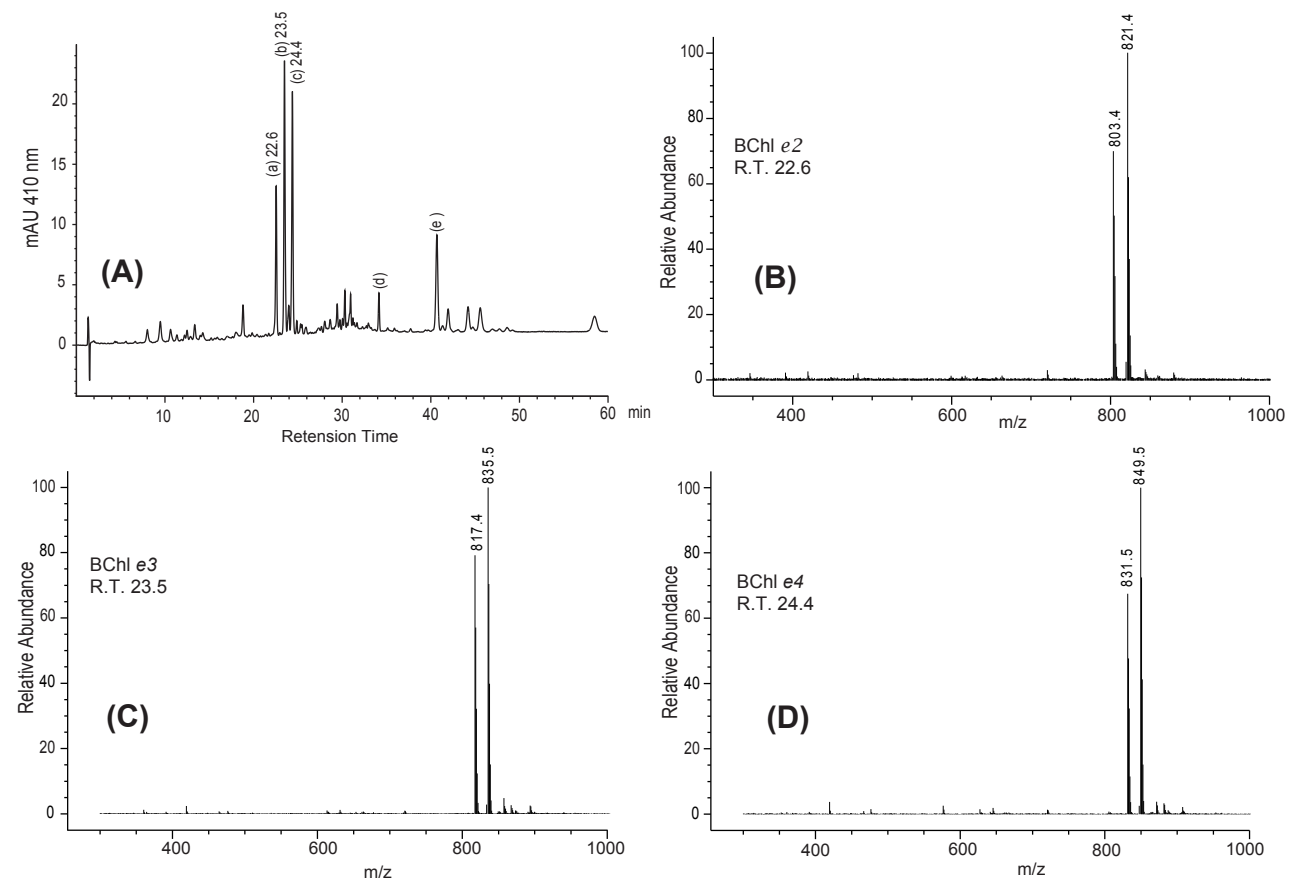

Fig. 4. (A) Representative chromatogram (LC-MS) obtained for suspended particulate matter having farnesyl-esterified bacteriochlorophyll $e$ isomers (Tillari Reservoir, 1 June 2010, 23 m). Major peaks (a), (b) and (c) represent BChl $e 2, e 3$ and $e 4$ respectively. Peaks (d) and (e) correspond to $\mathrm{Chl} a$ and isorenieratene respectively. (B) Confirmative mass spectra (LC-MS) for the peak (a) at 22.6 min. representing $e 2$ (Et, Et) BChl $e_{\mathrm{F}}$ isomer $\left(m / z=821.4,803.4\left(-\mathrm{H}_{2} \mathrm{O}\right)\right)$. (C) Peak (b) at 23.5min. representing $e 3(\mathrm{n}-\mathrm{Pr}, \mathrm{Et}) \mathrm{BChl} e_{\mathrm{F}}$ isomer $(m / z=835.5,817.4$ $\left(-\mathrm{H}_{2} \mathrm{O}\right)$ ). (D) Peak (c) at 24.4 min. representing $e 4$ (i-Bu, Et) BChl $e_{\mathrm{F}}$ isomer $\left(\mathrm{m} / z=849.5,831.5\left(-\mathrm{H}_{2} \mathrm{O}\right)\right)$. R.T. denotes retention time.

In January, phytoplankton community structure in the Tillari Reservoir was dominated by $\mathrm{Chl} b$-containing green algae and cyanobacteria with minor presence of diatoms in the epilimnion; however, these pigments were also present in deeper waters (Table 1) presumably due to vertical mixing. Although zeaxanthin is present in green algae as well as cyanobacteria, the presence of other accessory marker pigments such as violaxanthin, lutein and neoxanthin, not found in cyanobacteria confirms the presence of green algae (Jeffrey and Vesk, 1997). Phaeophytin $a$ concentration in bottom waters was high, between May and July (0.11 to $0.45 \mu \mathrm{g} 1^{-1}$ ), compared to that observed during January (BDL-0.42 $\mu \mathrm{g} \mathrm{l}^{-1}$ ). This could be attributed to better preservation in anoxic waters. Such observations have previously been reported from the Black Sea and other anoxic zones (Sinninghe Damste et al., 1993; Chen et al., 2001; Squier et al., 2002). A recent study of pigment composition in Petit Saut, a tropical reservoir in French Guiana, showed the dominance of Chlorophyceae (Chl $a$, Chl $b$ and lutein) in the oxic epilimnion, and anoxygenic photo-autotrophic bacteria below the oxycline as revealed by $\mathrm{BChl} c$ and $\mathrm{BChl}$ $d$ (Junet et al., 2009). An example of how the community structure of phytoplankton is dependent on nutrient availability is provided by the results of Zhu et al. (2010) from Taihu Lake (China) where Chlorophyta were found to be predominant at high concentrations of nitrogen and phosphorus, whereas cyanobacteria dominated in waters having low concentrations of these nutrients. Our data suggest co-existence of both these groups in the Tillari Reservoir.

\subsection{Anoxygenic photosynthesis in Tillari and Selaulim reservoirs during summer stratification}

As described under Sect. 3.1.2, the highest concentration of farnesyl-esterified $\mathrm{BChl} e$ homologues was in the upper portion of the anoxic layer where the $\mathrm{H}_{2} \mathrm{~S}$ concentration was low $(0.42 \mu \mathrm{M}$; Fig. 3a and b) corresponding to $0.2 \%$ of the surface incident light (Fig. 3c). Garcia-Gil and Abella (1992) studied photo-autotrophic bacterial populations in Spanish lakes and found the amount of light reaching the oxic-anoxic boundary to be the most important factor controlling their populations. However, they reported higher light intensities at the oxyclines of these lakes where $\mathrm{BChl} a$ and $e$ isomers were found in high concentrations. In a study carried out in two meromictic basins of Lake Banyoles, Borrego et al. (1999b) observed high concentration of $\mathrm{BChl} e$ isomers (up to $200 \mu \mathrm{g} \mathrm{l}^{-1}$ ) at $\sim 18 \mathrm{~m}$ depth and as summer stratification proceeded, the population of $\mathrm{Cb}$. pheobacteroides (bacterial plate) moved to shallower depth $(\sim 17 \mathrm{~m})$. They ascribed the upward migration from $18 \mathrm{~m}$ to $16.5 \mathrm{~m}$ to the increase in light intensity at the bacterial plate corresponding to a change from 0.004 to $0.05 \%$ of the surface incident 


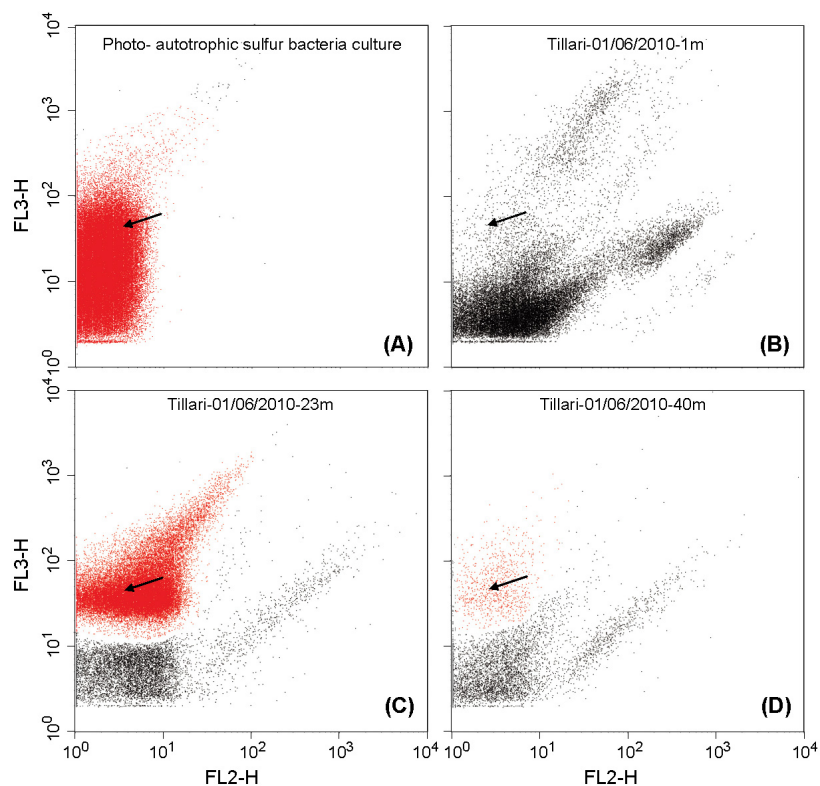

Fig. 5. Flow cytometry (FACS Calibur) analysis of photoautotrophic sulfur bacteria shown in red colour with an arrow. (A) Represents mixed culture of sulphur bacteria, while natural population in Tillari Reservoir at $1 \mathrm{~m}, 23 \mathrm{~m}$ and $40 \mathrm{~m}$ are shown in dot plots (B), (C) and (D) respectively. FL3-H and FL2-H indicates red and orange fluorescence.

light. These results illustrate the adaptability of the anoxygenic photosynthetic community to very low incident light levels. Although farnesol is the main alcohol esterifying the bacteriochlorophylls at position C-17, earlier studies have shown that a number of other alcohols are present in natural samples (Caple et al., 1978; Otte et al., 1993) depending on growth conditions, light intensity and stage of development of the cell (Borrego and Garcia-Gil, 1995; Airs et al., 2001b). Massé et al. (2004) reported that in cultured $C b$. phaeobacteroides, the isoprenoid esterified side chains dominated at low light intensities, while the straight-chain alkyl substituents dominated at higher light intensities. This phenomenon is explained as a result of changing availability of reducing power, i.e. the highly reduced straight-chain alcohols have a higher biosynthetic demand for $\mathrm{NADPH}_{2}$ than the polyunsaturated isoprenoid with the same number of carbon atoms (Massé et al., 2004). In the present study, we found the dominant bacteriochlorophylls to be farnesyl esterified (BChl $e_{\mathrm{F}}$ ) isomers based on their MS spectra, in comparison with the standards (extracted from Salt Pond, USA), and previous literature.

Although optical measurements were not made in the Selaulim Reservoir, the vertical distribution patterns of $\mathrm{H}_{2} \mathrm{~S}$ and $\mathrm{BChl} e$ isomers described in Sect. 3.2, are very similar to those observed in the Tillari Reservoir and it is reasonable to conclude that the anoxygenic bacterial population is controlled by the combined availability of free sulfide and light.

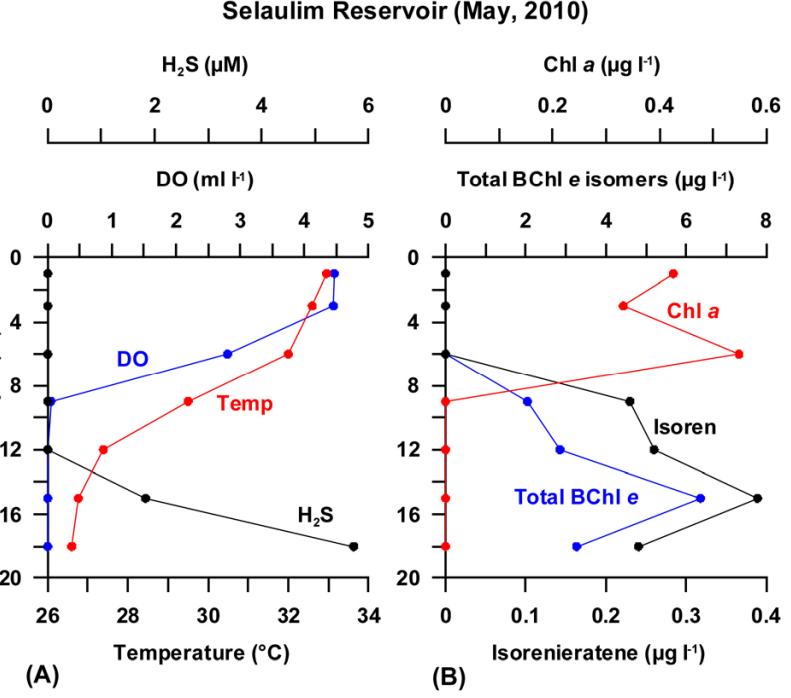

Fig. 6. (A) Vertical profiles of temperature $\left({ }^{\circ} \mathrm{C}\right)$, dissolved oxygen (DO; $1 \mathrm{ml} \mathrm{l}^{-1}=1.42 \mathrm{mgl}^{-1}$ ) and $\mathrm{H}_{2} \mathrm{~S}(\mu \mathrm{M})$ in Selaulim Reservoir during 21 May 2010. (B) Vertical profiles of Chl $a$, total BChl $e$ isomers $(e 2+, e 3+e 4)$ and isorenieratene $\left(\mu \mathrm{g}^{-1}\right)$ in Selaulim Reservoir.

In both Tillari and Selaulim reservoirs, we found bacteriochlorophyll $e 2, e 3$ and $e 4$ isomers typical of brown colored GSB thriving under low light conditions in natural habitats (Borrego et al., 1997). Among these isomers, the contributions of larger alkyl substituents [(n-Pr, Et) BChl $e_{\mathrm{F}}(42 \%)$ and (i-Bu, Et) $\mathrm{BChl} e_{\mathrm{F}}(\sim 34 \%)$ ] were higher in both the reservoirs as compared to (Et, Et) $\mathrm{BChl} e_{\mathrm{F}}$ isomer $(\sim 24 \%)$. An increase in the amount of homologues with larger alkyl substituents on the bacteriochlorophylls modifies the aggregation and therefore the packing of structures in the chlorosomes, with an impact on the in vivo absorption spectrum (Airs et al., 2001b), which might provide a basis for a cellular response to light limitation (Borrego et al., 1999b). The isomer $e l\left[(\mathrm{Et}, \mathrm{Me}) \mathrm{BChl} e_{\mathrm{F}}\right]$ was absent in these systems, as it is clearly traceable only in laboratory cultures grown under high light intensities (Borrego and Garcia-Gil, 1994, 1995). Isorenieratene, a carotenoid characteristic of brown sulfur bacteria was reported earlier in stratified anoxic basins having bacteriochlorophyll $e$ homologues (Garcia-Gil and Abella, 1992; Borrego et al., 1997, 1999b). We also measured isorenieratene in Tillari Reservoir during our June observation (Fig. 3b), which showed similar vertical profile of $\mathrm{BChl} e$ isomers. Isorenieratene was found to be present in Selaulim Reservoir also with highest concentration of $0.39 \mu \mathrm{g}{ }^{-1}$ at $15 \mathrm{~m}$ (Fig. 6b) where BChl $e$ isomers showed the highest concentration. This further supports the presence of anoxygenic photosynthesis in these reservoirs during summer stratification. 


\subsection{Standing stocks of oxygenically- and anoxygenically-photosynthesized carbon in the Tillari Reservoir}

Earlier estimates of carbon fixation in lakes by photosynthetic sulfur bacteria vary widely depending on sulfide and light availability (Parkin and Brock, 1980 and references therein). In the present study, the total concentration of bacteriochlorophyll $e$ isomers was used as a proxy of biomass of green sulfur bacteria. Yacobi and Ostrovski (2011) reported photosynthesis by microalgae and cyanobacteria to be the major source of organic particles in the epilimnion of Lake Kinneret, while green sulfur bacteria (Chlorobium phaeobacteroides) was found in the anoxic layer throughout the periods of stratification (Bergstein et al., 1979). In the Tillari Reservoir too farnesyl-esterified bacteriochlorophyll $e$ homologues ( $e 2, e 3$ and $e 4$ isomers) were the dominant pigments in the anoxic hypolimnion during summer stratification, while Chl $a$ was largely restricted to the epilimnion. We calculated the $\mathrm{BChl} e$ standing stock $\left(\mathrm{mg} \mathrm{m}^{-2}\right)$ for the June observation by integrating the total $\mathrm{BChl} e$ concentration in the anoxic compartment $(\sim 11-45 \mathrm{~m})$. The columnintegrated $\mathrm{BChl} e\left(113.8 \mathrm{mg} \mathrm{m}^{-2}\right)$ converted to carbon using the published value of the $\mathrm{BChl} e: \mathrm{C}$ ratio $(1: 20)$ yields a standing stock of $2.27 \mathrm{~g} \mathrm{~m}^{-2}$ of anoxygenically photosynthesized carbon. In comparison, with a Chl $a$ of $20.45 \mathrm{mg} \mathrm{m}^{-2}$ (0-45 m water column), the standing stock of oxygenically photosynthesized carbon, calculated using a $\mathrm{Chl} a: \mathrm{C}$ ratio of $1: 40$ comes to $0.82 \mathrm{~g} \mathrm{C} \mathrm{m}^{-2}$. This is similar to the results of Camacho et al. (2000) from Lake Arcas (Spain) who reported high population densities of phototrophic micro organisms with high concentration of BChl $a$ (up to $381 \mu \mathrm{g}^{-1}$ ) at the oxic-anoxic interface. The anoxic layer (9.1-9.8 m) in this lake accounted for $101.8 \mathrm{mg} \mathrm{BChl} a \mathrm{~m}^{-2}$, while the standing stock of $\mathrm{Chl} a$ from surface to $9.8 \mathrm{~m}$ was lower (72.1 $\mathrm{mg} \mathrm{m}^{-2}$ ).

In an earlier study by Takahashi and Ichimura (1968) carried out in stratified lakes in Japan, organic matter synthesized by photosynthetic sulfur bacteria in the reducing zone was reported to contribute $9-25 \%$ of the total annual production in lakes rich in $\mathrm{H}_{2} \mathrm{~S}$ and $3-5 \%$ in lakes poor in $\mathrm{H}_{2} \mathrm{~S}$. In another study by Steenbergen (1982) in Lake Vechten (the Netherlands), the photosynthetic sulfur bacteria accounted for 3.9 to $17.5 \%$ of total daily productivity in the pelagic zone. We do not have data on C-fixation rates to quantify the contribution of GSB to the total production in the two reservoirs sampled by us. One would expect the oxygenic photosynthetic production to exceed the anoxygenic photosynthetic production simply because it is the former that supplies the organic matter for the anaerobic metabolism. This ultimately leads to the production of $\mathrm{H}_{2} \mathrm{~S}$ thus fuelling the anoxygenic photosynthesis indirectly. Algal biomass build-up in the surface layer of the Tillari Reservoir during summer stratification was limited by low concentrations of nitrate $\left(\mathrm{NO}_{3}^{-}+\mathrm{NO}_{2}^{-}=1.21 \mu \mathrm{M}\right)$ and phosphate
$(0.08 \mu \mathrm{M})$ (Narvenkar et al., 2012), but production during the preceding winter/spring periods should have been higher. Although some studies have reported that protozoa predate upon green sulfur bacteria (Sacca et al., 2009), the grazing pressure upon algal populations is presumably higher causing a great impact on their standing stock. Thus, it is most likely that the high standing stock of green sulfur bacteria in the anoxic layer is the result of slow accumulation of biomass due to low grazing impact. It may be added that while data on phototrophic sulfur bacteria are presently limited to only two reservoirs, conditions favoring their growth also seem to exist in some other systems (Narvenkar et al., 2012). The potential significance of these organisms in biogeochemical cycling of fresh water systems of South Asia, indicated by our results, needs to be evaluated in detail.

Acknowledgements. The authors wish to thank the Director, NIO and managements of the Tillari and Selaulim reservoirs for permitting us to carry out the observations. We are grateful to H. Naik for logistical support and to H. Dalvi, A. Methar and B. R. Thorat for their kind assistance during sampling. $\mathrm{S}$. Patil is acknowledged for his assistance in flow cytometric analysis. Critical reviews by C. Abella, C. M. Borrego and R. de Wit greatly helped in improving the paper. Financial support for this work was provided by the Council of Scientific \& Industrial Research (CSIR) and Ministry of Earth Sciences (MoES). S. Kurian acknowledges POGO-SCOR for financial support to visit WHOI. R. Roy, G. Narvenkar and A. Sarkar received fellowship support from CSIR. D. Repeta acknowledges support from US National Science Foundation Center Award EF0424599 to the Center for Microbial Oceanography: Research and Education (C-MORE). This is NIO Contribution Number 5181.

Edited by: J. Middelburg

\section{References}

Airs, R. L., Atkinson, J. E., and Keely, B. J.: Development and application of a high resolution liquid chromatographic method for the analysis of complex pigment distributions, J. Chromatogr., A 917, 167-177, 2001a.

Airs, R. L., Borrego, C. M., Garcia-Gil, J., and Keely, B. J.: Identification of the bacteriochlorophyll homologues of Chlorobium phaeobacteroides strain UdG 6053 grown at low light intensity, Photosynth. Res., 70, 221-230, 2001 b.

Airs, R. L. and Keely, B. J.: Atmospheric pressure chemical ionisation liquid chromatography/ mass spectrometry of bacteriochlorophyll from Chlorobiaceae, characteristic fragmentation, Rapid Commun. Mass Spectrom., 16, 453-461, 2002.

Bañeras, L. and Garcia-Gil, L.J.: Role of photosynthetic microbial populations in the phosphorous exchange through the oxicanoxic boundary in a meromictic eutrophic lake, Arch. Hydrobiol. Spec. Issues Adv. Limnol., 48, 171-181, 1996.

Bergstein, T., Henis, Y., and Cavari, B. Z.: Investigations on the photosynthetic sulfur bacterium Chlorobium phaeobacteroides causing seasonal blooms in Lake Kinneret, Can. J. Microbiol., 25, 999-1007, 1979. 
Biebl, H. and Pfennig, N.: Anaerobic $\mathrm{CO}_{2}$ uptake by phototrophic bacteria: A review, Arch. Hydrobiol. Beih. Ergeb, Limnol, 12, 48-58, 1979.

Borrego, C. M. and Garcia-Gil, J.: Separation of bacteriochlorophyll homologues from green photosynthetic sulfur bacteria by reversed-phase HPLC, Photosynth. Res., 41, 157-163, 1994.

Borrego, C. M. and Garcia-Gil, L. J.: Rearrangement of light harvesting bacteriochlorophyll homologues as a response of green sulfur bacteria to low light intensities, Photosynth. Res., 45, 2130, 1995.

Borrego, C. M., Garcia-Gil, L. J., Vila, X. P., Figueras, J. B., and Abella, C. A.: Distribution of bacteriochlorophyll homologues in natural populations of brown-colored phototrophic sulfur bacteria, FEMS Microbiol. Ecol., 24, 301-309, 1997.

Borrego, C. M., Arellano, J. B., Abella, C. A., Gillbro, T., and Garcia-Gil, L. J.: The molar extinction coefficient of bacteriochlorophyll $e$ and the pigment stoichiometry in Chlorobium phaeobacteroides, Photosynth. Res., 60, 257-264, 1999a.

Borrego, C. M., Bañeras, L., and Garcia-Gil, L. J.: Temporal variability of Chlorobium phaeobacteroides antenna pigments in a meromictic karstic lake, Aquat. Microb. Ecol., 17, 121-129, 1999b.

Camacho, A., Vicente, E., and Miracle, M. R.: Spatio-temporal distribution and growth dynamics of phototrophic sulfur bacteria populations in the sulfide-rich Lake Arcas, Aquat. Sci., 62, 334349, 2000.

Caple, M. B., Chow, H., and Strouse, C. E.: Photosynthetic pigments of green sulphur bacteria: The esterifying alcohols of bacteriochlorophylls $c$ from Chlorobium limicola, J. Biol. Chem., 253, 6730-6737, 1978.

Casamayor, E. O., Ferrera, I., Cristina, X., Borrego, C. M., and Gasol, J. M.: Flow cytometric identification and enumeration of photosynthetic sulfur bacteria and potential for ecophysiological studies at the single-cell level, Environ. Microbiol., 9, 19691985, 2007.

Chen, C., Bianchi, T. S., McKee, B. A., and Bland, J. M.: Historical trends of hypoxia on the Louisiana shelf: Application of pigments as biomarkers, Org. Geochem., 32, 543-561, 2001.

Cole, J. J., Carpenter, S. R., Kitchel, J. F, and Pace, M. L.: Pathways of Organic Carbon Utilization in Small Lakes: Results from a Whole-Lake 13C Addition and Coupled Model, Limnol. Oceanogr., 47, 1664-1675, 2002.

Garcia-Gil, L. J. and Abella, C. A.: Population dynamics of phototrophic bacteria in three basins of Lake Banyoles (Spain), Hydrobiologia, 243/244, 87-94, 1992.

Garcia-Gil, L. J., Sala-Genoher, L., Esteva, J. V., and Abella, C. A.: Distribution of iron in Lake Banyoles in relation to the ecology of purple and green sulfur bacteria, Hydrobiologia, 192, 259-270, 1990.

Glaeser, J., Bañeras, L., Rütters, H., and Overmann, J.: Novel bacteriochlorophyll $e$ structures and species-specific variability of pigment composition in green sulfur bacteria, Arch. Microbiol., 177, 475-485, 2002.

Gerola, P. D. and Olson, J. M.: A new bacteriochlorophyll $a$ protein complex associated with chlorosomes of green sulfur bacteria, Biochim. Biophys. Acta, 848, 69-76, 1986.

Grasshoff, K., Erhardt, M., and Kremiling, K.: Methods of seawater analysis, Verlag Chemie, 419 pp., 1983.
Gregg, W. W. and Carder, K. L.: A simple solar irradiance model for cloudless maritime atmospheres, Limnol. Oceanogr., 35, 1657$1675,1990$.

Hirabayashi, H., Ishii, T., Takaichi, S., Inoui, K., and Uejara, K.: The Role of carotenoids in the photoadaptation of the brown colored sulfur bacterium Chlorobium phaeobacteroides, Photochem. Photobiol., 79, 280-285, 2004.

Hurley, J. P. and Watras, C. J.: Identification of bacteriochlorophylls in lakes via reverse-phase HPLC, Limnol. Oceanogr., 36, 307315, 1991.

Imhoff, J. F.: Taxonomy, phylogeny and general ecology of anoxygenic phototrophic bacteria, in: Biotechnology Handbook Photosynthetic Prokaryotes, edited by: Carr, N. G. and Mann, N. H., London \& New York, Plenum, 53-92, 1992.

Jeffrey, S. W. and Vesk, M.: Introduction to marine phytoplankton and their pigment signatures, in: Phytoplankton Pigments in Oceanography, edited by: Jeffrey, S. W., Mantoura, F. C., and Wright, S. W., UNESCO Publishing, Paris, 85-126, 1997.

Junet, A. de, Abril, G., Guèrin, F., Billy, I., and Wit, R. de.: A multitracers analysis of sources and transfers of particulate organic matter in a tropical reservoir (Petit Saut, French Guiana), River Res. Appli., 25, 253-271, 2009.

Marie, D., Partensky, F., Jacquet, S., and Vaulot, D.: Enumeration and cell cycle analysis of natural populations of marine picoplankton by flow cytometry using the nucleic acid stain SYBR Green I, Appl. Environ. Microbiol., 63, 186-193, 1997.

Massé, A., Airs, R. L., Keely, B. J., and Wit, R. de.: The impact of different intensities of green light on the bacteriochlorophyll homologue composition of the chlorobiaceae Prosthecochloris aestuarii and Chlorobium phaeobacteroides, Microbiol., 150, 25552564, 2004.

Narvenkar, G., Naqvi, S. W. A., Kurian, S., Shenoy, D. M., Pratihary, A. K., Naik, H., Patil, S., Sarkar, A., and Gauns, M.: Dissolved methane in Indian freshwater reservoirs, Environ. Monit. Assess., in review, 2012.

Oelze, J. and Golecki, J. R.: Growth rate and the control of development of the photosynthetic apparatus in Chloroflexus aurantiacus as studied on the basis of cytoplasmatic membrane structure and chlorosome size, in: Green Photosynthetic Bacteria, edited by: Olson, J. M., Ormerod, J. G., Amesz, J. Ormerod, J. G., Amesz, J., Stackebrandt, E., and Trüper, H. G., EMBO Workshop, Nyborg, Denmark, 35-42, 1988.

Otte, S. C. M., Van de Meent, J. E., van Veelen, P. A., Pundsnes, A. S., and Amesz, J.: Identification of the major chlorosomal bacteriochlorophylls of the green sulfur bacteria Chlorobium vibrioforme and Chlorobium phaeobacteroides; their function in lateral energy transfer, Photosynth. Res., 35, 159-169, 1993.

Parkin, T. B and Brock, T. D.: Photosynthetic bacterial production in lakes: The effects of light intensity, Limnol. Oceanogr., 25, 711-718, 1980.

Petzold, T. J.: Volume scattering functions for selected ocean waters, Scripps Inst. Oceanogr., Report SI0, 72-78, 1972.

Pfennig, N.: Ecology of phototrophic purple and green sulfur bacteria, in: Autotrophic bacteria, edited by: Schlegel, H. G. and Bowien, B., Springer Verlag, New York, 97-116, 1989.

Pfennig, N. and Trüper, H. G.: Anoxygenic phototrophic bacteria, in: Bergey's manual of systematic bacteriology, edited by: Staley, J. T., Bryant, M. P., Pfenning, N., and Holt, J. G., Baltimore: Williams and Wilkins, 3, 1635-1709, 1989. 
Pfennig, N. and Trüper HG.: The family Chromatiaceae, in: The Prokaryotes, edited by: Balows, A., Trüper, H. G., Dworkin, M., Harder, W., and Schleifer, K. H., Springer, New York, 2nd edn, 3200-3221, 1992.

Roy, R., Prathihary, A., Mangesh, G., and Naqvi, S. W. A.: Spatial variation of phytoplankton pigments along the south west coast of India, Estuar. Coast. Shelf Sci., 69, 189-195, 2006.

Sacca, A., Borrego, C. M., Renda, R., Triado-Margarit, X., Bruni, V., and Guglielmo, L.: Predation impact of ciliated and flagellated protozoa during a summer bloom of brown sulfur bacteria in a meromictic coastal lake, FEMS Microbiol. Ecol., 70, 42-53, 2009.

Senge, M. O. and Smith, K. M.: Biosynthesis and structures of the bacteriochlorophylls, in: Anoxygenic Photosynthetic Bacteria, Advances in Photosynthesis, edited by: Blankenship, R. E., Madigan, M. T., and Bauer, C. E., Kluwer Academic Publishers, Dordrecht, The Netherlands, Vol II, 137-151, 1995.

Sinninghe Damste, J. S., Wakeham, S. G., Kohnen, M. E. L., Hayes, J. M., and De Leeuw, J. W.: A 6,000-year sedimentary molecular record of chemocline excursions in the Black Sea, Nature, 362, 827-829, 1993.

Squier, A. H., Hodgson, D. A., and Keely, B.: Sedimentary pigments as markers for environmental change in an Antarctic lake, Org. Geochem., 33, 1655-1665, 2002.

Steenbergen, C. L. M.: Contribution of photosynthetic sulfur bacteria to primary production in Lake Vechten, Hydrobiologia, 95, 59-64, 1982.
Takahashi, M. and Ichimura, S.: Vertical distribution and organic matter production of photosynthetic sulfur bacteria in Japanese lakes, Limnol. Oceanogr., 13, 644-655, 1968.

Vaulot, D.: CYTOPC: Processing software for flow cytometric data, Signal and Noise, 2, 8 pp., 1989.

Vila, X. and Abella, C. A.: Effects of light quality on the physiology and the ecology of planktonic green sulfur bacteria in lakes, Photosynth. Res., 41, 53-65, 1994.

Vila, X., Abella, C. A., Figueras, J. B., and Hurley, J. P.: Vertical models of phototrophic bacterial distribution in the metalimnetic microbial communities of several freshwater North-American kettle lakes, FEMS Microbiol. Ecol., 25, 287-299, 1998.

Yacobi, Y. Z. and Ostrovsky, I.: Downward flux of organic matter and pigments in Lake Kinneret (Israel): relationships between phytoplankton and the material collected in sediment traps, J. Plankton Res., 30, 1189-1202, 2008.

Yacobi, Y. Z. and Ostrovsky, I.: Sedimentation of photosynthetic pigments during the bloom of the green sulfur bacterium Chlorobium phaeobacteroides in Lake Kinneret: spatial patterns, Hydrobiologia, 660, 117-124, 2011.

Yacobi, Y. Z., Eckert, W., Trueper, H. G., and Berman, T.: High performance liquid chromatography detection of phototrophic bacterial pigments in aquatic environments, Microbial. Ecol., 19, 127-136, 1990.

Zhu, W., Wan, L., and Zhao, L.: Effect of the nutrient level on phytoplankton community structure in different water bodies, J. Environ. Sci., 22, 32-39, 2010. 